University of Nebraska - Lincoln

DigitalCommons@University of Nebraska - Lincoln

Performance of Mouse Lines Divergently Selected for Heat Loss

When Exposed to Different Environmental Temperatures. I.

Reproductive Performance, Pup Survival, and Metabolic

Hormones

P. M. Kgwatalala

Botswana College of Agric.

J. L. DeRoin

Jackson, NE

Merlyn K. Nielsen

University of Nebraska-Lincoln, mnielsen1@unl.edu

Follow this and additional works at: https://digitalcommons.unl.edu/animalscifacpub

Part of the Animal Sciences Commons

Kgwatalala, P. M.; DeRoin, J. L.; and Nielsen, Merlyn K., "Performance of Mouse Lines Divergently Selected for Heat Loss When Exposed to Different Environmental Temperatures. I. Reproductive Performance, Pup Survival, and Metabolic Hormones" (2004). Faculty Papers and Publications in Animal Science. 515.

https://digitalcommons.unl.edu/animalscifacpub/515

This Article is brought to you for free and open access by the Animal Science Department at DigitalCommons@University of Nebraska - Lincoln. It has been accepted for inclusion in Faculty Papers and Publications in Animal Science by an authorized administrator of DigitalCommons@University of Nebraska - Lincoln. 


\title{
Performance of mouse lines divergently selected for heat loss when exposed to different environmental temperatures. I. Reproductive performance, pup survival, and metabolic hormones ${ }^{1}$
}

\author{
P. M. Kgwatalala ${ }^{2}$, J. L. DeRoin ${ }^{3}$, and M. K. Nielsen ${ }^{4}$ \\ Department of Animal Science, University of Nebraska, Lincoln 68583-0908
}

\begin{abstract}
Mouse populations differing in metabolic rate have been developed through selection for high (MH) and low (ML) heat loss, along with the unselected controls (MC). Objectives of the study were to compare the MH, ML, and MC lines for reproductive performance, pup survival, and metabolic hormones when reared at 12,22 , and $31^{\circ} \mathrm{C}$, and to search for line $\times$ environment interactions. Conception and litter size were recorded on the parent generation mice introduced to the environments at $11 \mathrm{wk}$ of age and bred after a 3 -wk acclimatization period. Survival of pups (preweaning to $3 \mathrm{wk}$; postweaning from 3 to 9 wk of age) was measured with continuous exposure in the designated environment from birth to the time of measurement. Corticosterone, triiodothyronine (T3), and thyroxine (T4) serum concentrations were measured on the parent generation after producing litters and on the pup generation at 9 wk. No line $\times$ environment interaction was detected for conception rate, preweaning mortality,
\end{abstract}

postweaning survival, pup weaning weight, or body temperature. There were no differences in conception rate among lines and environments. Environments affected survival of pups, but there were no line differences. Rectal body temperatures were greater for $\mathrm{MH}$ than ML mice, and MC mice were intermediate; body temperature of mice did not differ among the environments. Lines differed significantly in litter size only in the $22^{\circ} \mathrm{C}$ environment. No significant line differences were found for serum corticosterone or serum T3 or T4. Line $\times$ environment interaction was detected only for litter size and for serum corticosterone concentration in dams. Contrary to the other two lines, ML dam performance relative to $\mathrm{MH}$ and $\mathrm{MC}$ was not affected negatively by either of the thermal environments. Results from this study do not raise concern that selection to decrease maintenance requirements will produce livestock with any greater liability to cope and perform under an array of environmental temperatures.

Key Words: Ambient Temperature, Genotype $\times$ Environment Interaction, Metabolic Hormones, Mice, Mortality, Reproduction

(C)2004 American Society of Animal Science. All rights reserved.

J. Anim. Sci. 2004. 82:2876-2883

\section{Introduction}

One component of profitability of livestock enterprises is feed costs. Considerable variation in maintenance feed energy requirements exists among animals, and part of this variation is attributable to genetic causes (Bishop and Hill, 1985; Nielsen et al., 1997a). Selection for lower maintenance requirements is possi-

\footnotetext{
${ }^{1}$ A contribution of the Univ. of Nebraska Agric. Res. Div., Lincoln, NE, Journal Series No. 14212. This research was supported in part by funds provided through the Hatch Act.

${ }^{2}$ Current address: Botswana College of Agric., Private Bag 0027, Gaborone, Botswana.

${ }^{3}$ Current address: 1411 L Ave., Jackson, NE 68743.

${ }^{4}$ Correspondence: A218 Animal Sciences (phone: 402-472-6406; fax: 402-472-6362; e-mail: mnielsen1@unl.edu).

Received December 5, 2003.

Accepted June 14, 2004.
}

ble and is becoming a goal for some breeders to reduce production costs of livestock enterprises. With rearing under extensive conditions, animals are often subjected to seasonal variations in temperature and their associated possible stresses; thus, new selection goals must be evaluated in light of these ramifications.

Mouse populations differing in maintenance energy requirements have been developed through selection for high (MH) and low (ML) heat loss, along with unselected controls (MC), at the University of NebraskaLincoln (Nielsen et al., 1997b). Subjecting mice from the $\mathrm{MH}, \mathrm{MC}$, and ML lines to hot and cold environmental temperatures might therefore reveal the possible consequences on economically important traits of selecting for low maintenance requirements under different environmental temperatures.

The $a$ priori hypothesis for the study was that ML mice have lower thermal conductance and greater fat insulation than $\mathrm{MH}$ mice and should therefore perform 
better than $\mathrm{MH}$ mice in traits of economic importance in the cold environment. The MH mice have greater thermal conductance and less fat insulation than ML mice and should therefore have a comparative advantage in the hot environment, resulting in significant line $\times$ environment interactions.

The purpose of this study was to evaluate whether there are interactions among lines selected for heat loss or metabolic rate and environmental temperatures (12, 22 , and $31^{\circ} \mathrm{C}$ ) for reproductive performance, pup survival, and some metabolic hormones.

\section{Materials and Methods}

\section{Experimental Animals}

High heat loss, ML, and MC selection lines of mice, produced in the Animal Science Department at the University of Nebraska-Lincoln, were used for the investigation. The three lines were previously described by Nielsen et al. (1997a,b). Selection was practiced for high and low daily heat loss per unit of metabolic size (kcal-$\mathrm{kg}^{-0.75} \cdot \mathrm{d}^{-1}$ ), with heat loss measured in direct calorimeters; the other line was unselected and served as the control. The above selection criteria (MH, ML, and MC) were practiced in three independent replicates, giving a total of nine unique breeding lines, and the independent replicates were separated by a 5 -wk interval between the same stages in the life cycle. After selection for 16 generations, all of the lines were maintained with matings to minimize inbreeding within the lines. Mice sampled to initiate this study came from Generation 37, Replicate 3, and Generation 38, Replicates 1 and 2.

\section{Facilities}

Three environmentally controlled rooms were used in the investigation. The three rooms that served as the cold $(\mathbf{C})$, normal $(\mathbf{N})$, and hot $(\mathbf{H})$ environmental treatments were maintained at 12,22 , and $31^{\circ} \mathrm{C}$, respectively. We were limited to these extremes in our ability to control the temperature of the "cold" and "hot" rooms. The range of thermoneutrality for a mouse is recognized to be between 28 and $32^{\circ} \mathrm{C}$ (Gordon, 1993); thus, our "hot" room was not above thermoneutrality, although substantially above the usual temperature ( 22 to $23^{\circ} \mathrm{C}$ ) for mouse rearing. Humidity was monitored in the cold environmental chamber and averaged $42 \%$ for the entire study period. Humidity was not monitored in the other two environments, but it was expected to be lower than $40 \%$. All three rooms were equipped with overhead fluorescent lights and a timer to provide a controlled $12 \mathrm{~h}$ light:12 $\mathrm{h}$ darkness cycle for the entire study period.

\section{Management}

Throughout the study, mice were housed in plastic cages with stainless-steel wire-bar lids. Thirty females and 20 males of each line and replicate were introduced to each of the environmental treatments at $11 \mathrm{wk}$ of age. Females were housed in groups of six and males in groups of four per cage, each of the same selection criteria. All of the animals in one environment had littermate counterparts in the other two environments and were given ad libitum access to water and a regular maintenance diet (Teklad 8604: 24\% CP, $4 \%$ crude fat, and $4.5 \%$ crude fiber, as-fed basis; Harlan Teklad, Madison, WI). After a 3-wk acclimatization period, females were housed in groups of three, and one male of the same selection criterion was introduced to the females for breeding purposes. Eighteen days after the introduction of the males to the females, females were housed singly, given some nesting material (Nestlets, Ancare Corp., Waupaca, WI) and fed a lactation diet (Teklad 8626: $20 \%$ CP, $10 \%$ crude fat, and $3.0 \%$ crude fiber, asfed basis; Harlan Teklad, Madison, WI).

Upon giving birth, the number of pups born per dam, if greater than eight, was decreased to eight (ideally four males and four females) within $1 \mathrm{~d}$. No litters of less than eight at birth were retained. Pups were individually identified and weaned at 3 wk of age. Pups were housed six per cage for females and four per cage for males, for an intended total of 42 females and 40 males of each selection line and replicate across all environmental treatments. Due to breeding failure and poor survival of some pups, a few of the line-replicateenvironment classes had fewer animals. But all classes had at least 30 animals, except for MH females of Replicate 3 in the cold environment, which has 18. Pups had ad libitum access to water and a regular maintenance diet (Teklad 8604) up to 9 wk of age, at which time the experiment was terminated. Cages were changed twice weekly in the cold environment and once weekly in the other environments for the entire study period. The temperature-humidity combination in the cold environment limited evaporation from the bedding, thus cages/ bedding required more frequent changes. In addition, animals in the cold environment had greater feed intake, and hence, greater feces production. All research activity was conducted under IACUC Protocol No. 0109-062.

\section{Measurement of Traits}

The number of pups born per dam was recorded for each dam within $24 \mathrm{~h}$ after birth before standardizing litter size to eight pups. The number of live and fully formed pups was considered to be the litter size born. Preweaning mortality was recorded for each female on a weekly basis until weaning, when the pups were 3 wk of age. Preweaning mortality rate was determined by recording the total number of dead pups per litter compared with the standardized litter size (eight pups per litter). Conception rate was determined by recording the number of females that produced litters compared with the number in breeding cages. Postweaning survival rate was determined by recording the 
number of mice that survived up to 9 wk of age compared with the number retained at weaning ( $3 \mathrm{wk}$ of age).

Body temperature was recorded on the parent generation mice subjected to different environmental temperatures. Rectal temperatures were recorded with a thermometer (model MC-01, OMRON, Healthcare, Inc., Vernon Hills, IL) at $17 \mathrm{wk}$ of age for males (end of breeding) and $20 \mathrm{wk}$ of age for females (after their pups were weaned). Collection of temperature data was begun after the initial replicate was completed. Thus, there were data for only two replicates.

Blood samples were taken by heart puncture immediately after the pups were killed at 9 wk and from parents at either $17 \mathrm{wk}$ for sires or $20 \mathrm{wk}$ for dams. All replicates of pups were represented, but only two replicates were represented in the parents sampled. Following coagulation, serum was drawn from each sample and frozen until hormone assays were performed. A total of 162 pups (three replicates $\times$ three lines $\times$ three environments $\times$ two sexes $\times$ three mice per replicateline-environment-sex) was sampled. The number of dams sampled was 54 (two replicates $\times$ three lines $\times$ three environments $\times$ three mice per replicate-line-environment), and the number of sires sampled was 36 (two replicates $\times$ three lines $\times$ two environments [hot and cold] $\times$ three mice per replicate-line-environment).

Serum samples were assayed for corticosterone, thyroxine (T4), and triiodothyronine (T3) using RIA kits purchased from Diagnostic Products Corp. (Los Angeles, CA). Concentration standards for each assay were done in triplicate to obtain the standard curve for each set of assays, and each sample was then run in duplicate and averaged.

\section{Statistical Analyses}

Three levels of temperature environments $(12,22$, and $31^{\circ} \mathrm{C}$ ), three lines of mice (MH, ML, and $\left.\mathrm{MC}\right)$, three (two for body temperature) replicates, and the two sexes (males and females) were used in a $3 \times 3 \times 3 \times 2$ factorial arrangement in a completely randomized design. Most data analyses were by SAS (SAS Inst., Inc., Cary NC) using the mixed-model procedures of Littell et al. (1996). The Satterthwaite method for determining degrees of freedom was used in all analyses. The experimental model used in body temperature data included environment, line, sex, and the various interactions between the three factors as fixed effects. Random effects were replicates and the interactions between replicates and environment, line, environment $\times$ line, and environment $\times$ line $\times$ sex.

Subclass means for conception and preweaning mortality data were transformed to the logit and log scales, respectively, before the mixed-model analysis. After the transformation, all reproductive performance data (conception, preweaning mortality, and litter size data) were analyzed with temperature, line, and the interaction between the two factors as fixed effects, and the replicates and the various interactions between the replicates and the fixed factors as random effects. Sex was not included in the model because of the sex-limited nature (expressed only in females) of the aforementioned reproductive traits. After the analysis, conception and preweaning mortality data were retransformed to their original scale of measurement for presentation of means. Because data were transformed to the logit and log scales, standard errors could not be calculated for the retransformed means. Instead, 95\% confidence intervals were calculated and then retransformed to the original scales of measurement. Logit least squares means for survival and conception rate were retransformed to their original scale of measurement as described by Azzam et al. (1989). Approximate 95\% confidence limits for the retransformed least squares means were obtained similarly by transforming the lower and upper 95\% interval extremes from the logit analysis.

Postweaning survival data were transformed to the logit scale, and analysis was by the GLM procedures of SAS. Means for various fixed factors were estimated using the weighted least squares procedures (Gianola, 1982; Rutledge and Gunsett, 1982). The logit scale ensures that estimated survival rates are between 0 and $100 \%$ and that the weighted least squares corrected for the differences in number of mice retained at weaning caused by high preweaning mortality in the cold environment. The weighting factor has been described by Gart and Zweifel (1967). The model used in the analysis of postweaning survival data was similar to the one described above.

Mean separations for the various fixed factors and the interactions between the fixed factors were done using sets of orthogonal contrasts. Selection criteria means were compared using orthogonal contrasts of 1 ) $[(\mathrm{MH}+\mathrm{ML}) / 2-\mathrm{MC}]$ to test for asymmetry of selection; and 2) MH vs. ML to test for selection response. Thermal environment effects were compared using orthogonal contrasts of 3$)[(\mathrm{H}+\mathrm{C}) / 2-\mathrm{N})]$ to test for nonlinear effects of temperature; and 4) $\mathrm{H}$ vs. C to test for the extreme effects of temperature. The remaining contrasts were tests for males vs. females and the various two-way and three-way interactions of line, environment, and sex.

Metabolic hormone data were analyzed in three sets: pups, dams, and sires. In preliminary analyses, log transformations were compared with raw data to see if variation within subclasses would be more similar. However, no gain from this transformation was found; thus, the data were analyzed and are reported in the original measure. Because the dams and sires were analyzed separately, the effect of sex in adult animals was not tested. In addition, only the effects of the two extreme environments could be tested in the sires.

Data are summarized in tables by line-environment classes (least squares means $\pm \mathrm{SE}$ or $95 \%$ confidence interval) if the line $\times$ environmental interaction was significant. Otherwise, only line means are presented 
Table 1. Least squares means $( \pm \mathrm{SE})$ for litter size by line-environment classes ${ }^{\mathrm{a}, \mathrm{b}}$

\begin{tabular}{lccr}
\hline \hline Environment & $\mathrm{MH}$ & $\mathrm{MC}$ & \multicolumn{1}{c}{$\mathrm{ML}$} \\
\hline Cold $\left(\mathrm{C}, 12^{\circ} \mathrm{C}\right)$ & $10.84 \pm 0.55$ & $10.59 \pm 0.55$ & $10.56 \pm 0.54$ \\
Normal $\left(\mathrm{N}, 22^{\circ} \mathrm{C}\right)$ & $11.73 \pm 0.54$ & $12.23 \pm 0.53$ & $10.22 \pm 0.53$ \\
Hot $\left(\mathrm{H}, 31^{\circ} \mathrm{C}\right)$ & $10.40 \pm 0.54$ & $10.37 \pm 0.54$ & $9.35 \pm 0.54$ \\
\hline
\end{tabular}

${ }^{\mathrm{a}} \mathrm{MH}=$ selected for high heat loss; $\mathrm{MC}=$ control; $\mathrm{ML}=$ selected for low heat loss.

bignificant contrasts: $(\mathrm{H}+\mathrm{C}) / 2-\mathrm{N}, P<0.01 ; \mathrm{H}-\mathrm{C}, P<0.10 ;[(\mathrm{MH}+\mathrm{ML}) / 2-\mathrm{MC}] \times[(\mathrm{H}+\mathrm{C}) / 2-\mathrm{N}]$, $P<0.01 ;[\mathrm{MH}-\mathrm{ML}] \times[(\mathrm{H}+\mathrm{C}) / 2-\mathrm{N}], P<0.10$.

for the remaining characteristics, and environment means are also presented where significance was detected. Significance of contrasts is presented with the tables. No three-way interactions were significant and therefore are not discussed.

\section{Results and Discussion}

\section{Line $\times$ Environment Interaction}

Means for number born (litter size) in the three lines at different environmental temperatures are given in Table 1 . There was a line $\times$ environment interaction $(P$ $<0.05)$ for litter size born. The contrast that explained most of this interaction was $[(\mathrm{MH}+\mathrm{ML}) / 2-\mathrm{MC}] \times[(\mathrm{H}$ $-\mathrm{C}) / 2-\mathrm{N}]$. Differences in litter size between the average of the selected lines (MH and ML) and the MC were smaller in the hot and cold environments than in the normal environment. In the normal environment, litter size of the MC was greater than that of both $\mathrm{MH}$ and ML. In the cold and hot environments, there were no differences in litter size between the three lines. There was, however, evidence of some divergence in litter size $(P<0.08)$ between the MH and ML lines in the normal environment. There was also a difference $(P<0.05)$ in litter size between the MC and ML (12.23 vs. 10.22 pups/litter) in the normal environment, but the difference was small and nonsignificant between the $\mathrm{MC}$ and MH lines (12.23 vs.11.73 pups per litter).

Nielsen et al. (1997a) observed a difference $(P<0.01)$ in litter size between the $\mathrm{MH}$ and ML lines with $\mathrm{MH}$ $>\mathrm{ML}$ at normal $\left(22^{\circ} \mathrm{C}\right)$ temperature, and the litter size in the MC line was intermediate to those in the ML and $\mathrm{MH}$ lines at Generation 15 of selection for heat loss. Fewer litters were measured in our study, and this might explain the failure of the results reported here to coincide with those reported at Generation 15 of selection. The MH and MC lines had greater average litter size in the normal environment, whereas the ML performed slightly better in the cold environment.

Barnett and Manly (1956) reported slight reductions in litter size in the C57BL and GFF strains as a result of cold exposure $\left(-3^{\circ} \mathrm{C}\right)$ and no effect on litter size in the A strain. Wilson et al. (1972) reported litter sizes of 7.94, 7.74, and 8.12 in one four-way composite strain of mice, and litter sizes of 8.55, 8.34, and 8.04 in another four-way composite strain in cold $\left(12^{\circ} \mathrm{C}\right)$, normal $\left(21^{\circ} \mathrm{C}\right)$, and hot $\left(30^{\circ} \mathrm{C}\right)$ environments, respectively.
The results obtained in this study for the $\mathrm{MH}$ and MC are therefore consistent with most of the above studies, which indicates a decrease in litter size as a result of either heat or cold exposure. The ML was unique, with no decrease in litter size in the cold environment. Heat and cold stress may adversely affect spermatogenesis and/or sperm characteristics in males and may also affect oogenesis in females or lead to resorption of fetuses in utero, which ultimately results in smaller litter sizes. The actual response will however, be dependent on the temperature of exposure, its constancy and its duration (Barnett, 1965).

The significant line $\times$ environment interaction for litter size is consistent with the a priori hypothesis for the study and indicates that litter size varied between the lines under different environmental temperatures. Differences in litter size between the MH and ML lines were much smaller in the cold environment than in the normal and hot environments. The largest litter size in the cold environment for the ML line is also consistent with the $a$ priori hypothesis and suggests an advantage for the ML line in the cold environment, possibly through lower thermal conductance and better body insulation (body fat and pelage). Maskrey et al. (2001) reported significantly lower body temperatures (37.1 vs. $37.3^{\circ} \mathrm{C}$ ) and preference for cooler ambient temperatures $\left(20.9\right.$ vs. $\left.22.7^{\circ} \mathrm{C}\right)$ in obese Zucker rats compared with their age-matched lean counterparts. The ML line had a significantly lower body temperature (see Table 2) than the MH line, and the preferred ambient temperature for the ML line may be lower than the normal laboratory temperature $\left(22^{\circ} \mathrm{C}\right)$, hence the increase in litter size in the cold environment. The result of slightly larger litters in the $\mathrm{MH}$ line than the ML line in the hot environment is also consistent with the a priori hypothesis and suggests a slight advantage in the $\mathrm{MH}$ line over the ML, possibly through higher thermal conductance from the animals' bodies conferred by less fat and pelage insulation.

No line $\times$ environment interaction was detected for conception rate, preweaning mortality, postweaning survival, pup weaning weight or body temperature, and means for these characteristics, by line and by environment, are listed in Tables 2 and 3, respectively.

Means for blood serum corticosterone level for lineenvironment classes of dams and for lines of pups and sires are provided in Table 4 . There was a line $\times$ environment interaction $(P<0.05)$ in data collected on dams, 
Table 2. Least squares means $( \pm \mathrm{SE}$ or $95 \% \mathrm{CI})$ by selection line for reproductive and maternal performance traits, postweaning survival, and body temperature

\begin{tabular}{|c|c|c|c|}
\hline Traits & $\mathrm{MH}^{\mathrm{a}}$ & $\mathrm{MC}$ & ML \\
\hline $\begin{array}{l}\text { Conception rate, } \%^{\mathrm{b}} \\
(95 \% \mathrm{CI})\end{array}$ & $\begin{array}{c}89.1 \\
(78.6 \text { to } 94.8)\end{array}$ & $\begin{array}{c}93.4 \\
(85.8 \text { to } 97.1)\end{array}$ & $\begin{array}{c}94.5 \\
(87.8 \text { to } 97.6)\end{array}$ \\
\hline $\begin{array}{l}\text { Preweaning mortality, } \text { pups }^{\mathrm{c}, \mathrm{d}} \\
(95 \% \mathrm{CI})\end{array}$ & $\begin{array}{c}1.59 \\
\text { (1.21 to } 2.09)\end{array}$ & $\begin{array}{c}1.60 \\
(1.22 \text { to } 2.09)\end{array}$ & $\begin{array}{c}1.55 \\
(1.17 \text { to } 2.06)\end{array}$ \\
\hline $\begin{array}{l}\text { Postweaning survival rate, } \%^{\mathrm{d}} \\
(95 \% \mathrm{CI})\end{array}$ & $\begin{array}{l}97.2 \\
\text { (96.6 to } 97.7)\end{array}$ & $\begin{array}{c}97.7 \\
(97.2 \text { to } 98.2)\end{array}$ & $\begin{array}{c}97.0 \\
(96.3 \text { to } 97.5)\end{array}$ \\
\hline Average weaning wt, $\mathrm{g}^{\mathrm{d}}$ & $12.92 \pm 0.51$ & $13.70 \pm 0.51$ & $12.84 \pm 0.51$ \\
\hline Body temperature, ${ }^{\circ} \mathrm{C}^{\mathrm{e}}$ & $37.77 \pm 0.14$ & $37.38 \pm 0.14$ & $37.00 \pm 0.14$ \\
\hline
\end{tabular}

${ }^{\mathrm{a}} \mathrm{MH}=$ selected for high heat loss; $\mathrm{MC}=$ control; $\mathrm{ML}=$ selected for low heat loss.

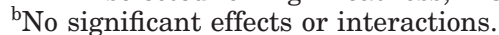

${ }^{\mathrm{c} N u m b e r}$ dead per litter at $3 \mathrm{wk}$ after standardization to eight pups at birth.

dNo significant contrast.

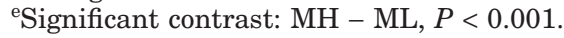

and this arose from both single degree of freedom contrasts: 1) $[(\mathrm{MH}+\mathrm{ML}) / 2-\mathrm{MC}] \times[\mathrm{H}-\mathrm{C}]$; and 2) $[\mathrm{MH}$ $-\mathrm{ML}] \times[\mathrm{H}-\mathrm{C}]$. The greater values of $\mathrm{MH}$ in the cold environment and $\mathrm{MC}$ in the hot environment contribute to the cause of these interactions. Observation and preliminary data with mice of these lines on reaction to restraint stress indicate that line $\mathrm{MH}$ is more stress susceptible, and ML is less stress susceptible. Concentration of corticosterone is associated with level of stress response, at least on an acute basis.

Besides corticosterone, the other characteristic that exhibited a line $\times$ environment interaction was litter size. The MH dams had greater litter size born than ML dams in the normal and hot environments, but not in the cold environment where litter size was quite similar for the two lines. Corticosterone level of dams was greatest in the $\mathrm{MH}$ line in the cold environment. A scenario could exist where $\mathrm{MH}$ dams were under more stress in the cold environment, and that might explain their smaller litter sizes relative to ML dams. But perhaps most importantly, from the standpoint of selection to reduce maintenance energy intake, litter size in ML was not decreased any further in the hot environment than in the normal, and ML had its best litter size performance in the cold environment.

Given that corticosterone is involved in carbohydrate, lipid, and fat metabolism, and that the young animals in this experiment consumed more feed in the cold environment and less in the hot environment (Kgwatalala and Nielsen, 2004), it is surprising that differences due to environment were not detected in the pups and sires. Although the $\mathrm{MH}$ dams had greater corticosterone concentrations in the cold environment, the greatest corticosterone concentrations in the MC and ML dams were in the hot environment. Evidently, physiological factors related to corticosterone and stress are more important than those related to corticosterone and metabolism of nutrients. Of course another explanation is the limited number of animals sampled across the environment and line classes.

No line $\times$ environment interactions $(P>0.35)$ were detected for either serum T3 or T4 concentrations.

\section{Line Effects}

Performance means of the three lines of mice for conception rate, preweaning mortality, postweaning sur-

Table 3. Least squares means ( \pm SE or $95 \% \mathrm{CI}$ ) by environmental temperature for reproductive and maternal performance traits, post-weaning survival rate, and body temperature

\begin{tabular}{lccc}
\hline \hline Traits & Cold $\left(12^{\circ} \mathrm{C}\right)$ & Normal $\left(22^{\circ} \mathrm{C}\right)$ & Hot $\left(31^{\circ} \mathrm{C}\right)$ \\
\hline $\begin{array}{l}\text { Conception rate, } \%^{\mathrm{a}} \\
(95 \% \mathrm{CI})\end{array}$ & 88.3 & 96.0 & 91.8 \\
${\text { Preweaning mortality, } \text { pups }^{\mathrm{b}}}^{(95 \% \mathrm{CI})}$ & 4.6 to 94.8$)$ & $(89.9$ to 98.5$)$ & $(81.9$ to 96.5$)$ \\
Postweaning survival rate, $\%^{\mathrm{c}}$ & $(3.31$ to 5.29$)$ & 0.68 & 1.39 \\
$(95 \% \mathrm{CI})$ & 91.9 & $(0.48$ to 0.96$)$ & (1.04 to 1.86$)$ \\
Average weaning wt, $\mathrm{g}^{\mathrm{d}}$ & $(90.5$ to 93.2$)$ & $(98.1$ to 98.7$)$ & 98.6 \\
Body temperature, $^{\circ} \mathrm{C}^{\mathrm{e}}$ & $11.54 \pm 0.49$ & $14.12 \pm 0.49$ & 198.2 to 98.8$)$ \\
\hline
\end{tabular}

${ }^{a}$ No significant effects or interactions.

${ }^{\mathrm{b}}$ Number dead per litter at $3 \mathrm{wk}$ after standardization to eight pups at birth.

Significant contrasts: $(\mathrm{H}+\mathrm{C}) / 2-\mathrm{N}, P<0.001 ; \mathrm{H}-\mathrm{C}, P<0.01$.

'Significant contrast: $\mathrm{H}-\mathrm{C}, P<0.05$.

dignificant contrasts: $(\mathrm{H}+\mathrm{C}) / 2-\mathrm{N}, P<0.02 ; \mathrm{H}-\mathrm{C}, P<0.005$.

${ }^{\mathrm{e} N o}$ significant contrast. 
Table 4. Least squares means $( \pm S E)$ for serum corticosterone $(\mathrm{ng} / \mathrm{mL})$ by line-environment classes for dams and by line for 9-wk-old pups and sires

\begin{tabular}{llcr}
\hline \hline Environment & \multicolumn{1}{c}{ MH $^{\mathrm{a}}$} & \multicolumn{1}{c}{$\mathrm{MC}$} & $\mathrm{ML}$ \\
\cline { 2 - 4 } & \multicolumn{4}{c}{ Dams $^{\mathrm{b}}$} \\
\cline { 2 - 4 } Cold $\left(\mathrm{C}, 12^{\circ} \mathrm{C}\right)$ & $446 \pm 120$ & $143 \pm 120$ & $108 \pm 124$ \\
Normal $\left(\mathrm{N}, 22^{\circ} \mathrm{C}\right)$ & $345 \pm 120$ & $199 \pm 120$ & $213 \pm 120$ \\
Hot $\left(\mathrm{H}, 31^{\circ} \mathrm{C}\right)$ & $392 \pm 120$ & $556 \pm 120$ & $369 \pm 120$ \\
Mean for pups & $149 \pm 26$ & $159 \pm 25$ & $167 \pm 25$ \\
Mean for sires & $116 \pm 23$ & $127 \pm 24$ & $80 \pm 24$ \\
\hline
\end{tabular}

${ }^{\mathrm{a}} \mathrm{MH}=$ selected for high heat loss; $\mathrm{MC}=$ control; $\mathrm{ML}=$ selected for low heat loss.

${ }^{\mathrm{b}}$ Significant contrasts: $[(\mathrm{MH}+\mathrm{ML}) / 2-\mathrm{MC}] \times[\mathrm{H}-\mathrm{C}], P<0.02$; $[\mathrm{MH}-\mathrm{ML}] \times[\mathrm{H}-\mathrm{C}], P<0.03$.

vival, and maternal traits, and body temperature are presented in Table 2. No significant differences between lines were detected in conception rate, preweaning mortality rate of the pups and postweaning survival. Differences between the three lines in average weaning weights of pups at 3 wk of age were also small and nonsignificant. Similar performance of all lines indicates that selection for high or low maintenance requirement had no correlated response in conception rate, mortality rate, or maternal traits of the females.

Rectal temperatures were different $(P<0.001)$ between the $\mathrm{MH}$ and $\mathrm{ML}$, and the MC was intermediate; hence, there was no asymmetry of selection response. The body temperature was also similar between males and females and averaged 37.37 and $37.39^{\circ} \mathrm{C}$ for females and males, respectively. The divergence in body temperature between the $\mathrm{MH}$ and $\mathrm{ML}$ noted above is consistent with the findings of Mousel et al. (2001), who reported significantly greater core body temperature in the $\mathrm{MH}$ than in the $\mathrm{ML}$ line $\left(37.19\right.$ vs. $36.68^{\circ} \mathrm{C}$, respectively). Selman et al. (2001) also reported marginally greater body temperatures in the high voluntary feed intake line of mice than in the low intake line.

The overall means for corticosterone concentration in dams of $394 \mathrm{ng} / \mathrm{mL}$ for $\mathrm{MH}$ and $230 \mathrm{ng} / \mathrm{mL}$ for $\mathrm{ML}$ (Table 4) are consistent with our observations that $\mathrm{MH}$ is less able to handle stressors and ML is less affected by stress and, concomitantly, more able to adapt to stress. Although not significant, mean corticosterone concentration for lines in the sires also ranked in the same order. But there was no indication of any differ-

Table 5. Least squares means $( \pm \mathrm{SE})$ for serum thyroxine (T4; ng/mL) by line for 9-wk-old pups, dams, and sires

\begin{tabular}{lccc}
\hline \hline Age & $\mathrm{MH}^{\mathrm{a}}$ & $\mathrm{MC}$ & $\mathrm{ML}$ \\
\hline Pups $^{\mathrm{b}}$ & $30.3 \pm 2.1$ & $33.1 \pm 2.0$ & $38.5 \pm 2.0$ \\
Dams & $31.3 \pm 2.1$ & $31.7 \pm 2.1$ & $32.4 \pm 2.1$ \\
Sires & $24.8 \pm 3.3$ & $22.4 \pm 3.3$ & $27.7 \pm 3.3$ \\
\hline
\end{tabular}

${ }^{\mathrm{a}} \mathrm{MH}=$ selected for high heat loss; $\mathrm{MC}=$ control; $\mathrm{ML}=$ selected for low heat loss.

${ }^{\mathrm{b}}$ Significant contrast: $\mathrm{MH}-\mathrm{ML}, P<0.07$.
Table 6. Least squares means $( \pm \mathrm{SE})$ for serum triiodothyronine (T3; pg/mL) by line-sex classes for 9-wk-old pups

\begin{tabular}{lccc}
\hline \hline Sex & $\mathrm{MH}^{\mathrm{a}}$ & $\mathrm{MC}$ & $\mathrm{ML}$ \\
\hline Males $(\mathrm{M})^{\mathrm{b}}$ & $1.98 \pm 0.26$ & $2.14 \pm 0.25$ & $2.35 \pm 0.25$ \\
Females (F) & $2.58 \pm 0.25$ & $1.77 \pm 0.25$ & $1.82 \pm 0.25$ \\
\hline
\end{tabular}

${ }^{\mathrm{a}} \mathrm{MH}=$ selected for high heat loss; $\mathrm{MC}=$ control; $\mathrm{ML}=$ selected for low heat loss.

${ }^{\mathrm{b}}$ Significant contrast: $[\mathrm{MH}-\mathrm{ML}] \times[\mathrm{M}-\mathrm{F}], P<0.01$.

ence between lines $(P>0.50)$ in serum corticosterone concentration in 9-wk-old pups.

Means for blood serum T4 concentration for lines of pups, dams, and sires are in Table 5. In pups, selection lines were significantly different in $\mathrm{T} 4$ concentration, and this was explained by the contrast of $\mathrm{MH}-\mathrm{ML}(P$ $<0.07)$; T4 concentration in MC animals was intermediate to the two selection lines. For dams and sires, no line differences were detected $(P>0.30)$ for T4 serum concentration. Sex of pups was a significant source of variation $(P<0.01)$, with males having a greater T4 level than females $(34.4 \pm 1.7$ vs. $27.9 \pm 1.7)$.

Serum T3 concentration means for line $\times$ sex classes of pups are given in Table 6, and for the three age groups in the three environments in Table 7. A line $\times$ sex interaction $(P<0.05)$ was detected in the pups and was due to the $[\mathrm{MH}-\mathrm{ML}] \times[$ males - females] contrast. In line $\mathrm{MH}$, females had greater $\mathrm{T} 3$ concentration than males; in line $\mathrm{ML}$, males had the greater T3 level in their serum than females.

\section{Environment Effects}

Differences in litter size (Table 1) between different environmental temperatures clearly exist, and all of the lines consistently produced the smallest litters in the hot environment. Biggers et al. (1958) observed litter sizes of 7.04, 7.25, and 8.06 for mice bred in hot $\left(28^{\circ} \mathrm{C}\right)$, cold $\left(5^{\circ} \mathrm{C}\right)$, and temperate $\left(21^{\circ} \mathrm{C}\right)$ environments, respectively.

Performance means observed in the three environments for conception rate, preweaning mortality, postweaning survival, and maternal traits, and body temperature are presented in Table 3 . Body temperature of mice did not differ $(P>0.50)$ among the environments. There were no differences $(P>0.10)$ in conception rate

Table 7. Least squares means $( \pm \mathrm{SE})$ for serum triiodothyronine (T3; pg/mmL) by environments for pups, dams, and sires

\begin{tabular}{lccc}
\hline \hline Age & Cold $\left(\mathrm{C}, 12^{\circ} \mathrm{C}\right)$ & Normal $\left(\mathrm{N}, 22^{\circ} \mathrm{C}\right)$ & Hot $\left(\mathrm{H}, 31^{\circ} \mathrm{C}\right)$ \\
\hline Pups $^{\mathrm{a}}$ & $2.60 \pm 0.19$ & $2.35 \pm 0.20$ & $1.62 \pm 0.20$ \\
Dams $^{\mathrm{b}}$ & $2.50 \pm 0.21$ & $1.95 \pm 0.21$ & $1.48 \pm 0.20$ \\
Sires $^{\mathrm{c}}$ & $2.22 \pm 0.17$ & - & $1.37 \pm 0.15$ \\
\hline
\end{tabular}

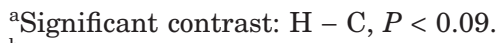

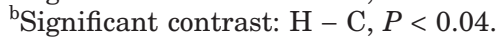

'Significant contrast: $\mathrm{H}-\mathrm{C}, P<0.001$. 
among the three environmental temperatures. The greatest conception rate $(96.0 \%)$ was however recorded in the normal $\left(22^{\circ} \mathrm{C}\right)$ environment and the lowest $(88.3 \%)$ in the cold environment. Barnett and Manly (1956), working with two inbred mouse lines, reported that at $-3{ }^{\circ} \mathrm{C}, 64 \%$ of all the C57BL matings and $38 \%$ of all the GFF matings were barren. Wettemann et al. (1976) reported that use of semen from heat-stressed boars $\left(34.5^{\circ} \mathrm{C}\right.$ for $8 \mathrm{~h}$ and $31^{\circ} \mathrm{C}$ for $16 \mathrm{~h}$ for $\left.90 \mathrm{~d}\right)$ resulted in $28 \%$ conception compared with the $41.2 \%$ conception rate in gilts bred with semen from the control boars maintained at $23^{\circ} \mathrm{C}$. Similar conception rates between different environmental temperatures are therefore contradictory to the findings of Barnett and Manly (1956) and Wettemann et al. (1976), who obtained significantly lower conception rates as a result of either cold or heat exposure. The results are, however, consistent with the findings of Wilson et al. (1972), who reported no significant differences in conception rate among the cold $\left(12^{\circ} \mathrm{C}\right)$, normal $\left(21^{\circ} \mathrm{C}\right)$, and hot $\left(30^{\circ} \mathrm{C}\right)$ environments $(84,88$, and $83 \%$ conception rates, respectively) in a four-way composite strain of mice. Similar conception rates between the three environmental temperatures may also be indicative of the high fertility and adaptive capabilities of this particular strain of mice to cold and heat stress.

Differences in preweaning mortality rate were significant among the three environmental temperatures. The difference in mortality between the extreme temperatures was large $(P<0.001)$. Because the lowest mortality rate was in the normal environment, there was asymmetry $(P<0.005)$ in preweaning mortality due to temperature. The highest mortality occurred in the cold environment and the lowest in the normal environment. Preweaning mortality rate in the hot and cold environments represented increases of 104 and 516\%, respectively, over the mortality rate in the normal environment. The higher mortality rate in the cold environment was mainly due to mortality of whole litters, and $95 \%$ of all the mortalities in the cold environment occurred during the first week of life. The high preweaning mortality rate experienced by mice in the cold environment is consistent with the findings of Barnett and Manly (1956); they reported heavy preweaning mortality in the C57BL and GFF strains at $-3^{\circ} \mathrm{C}$ compared with $21^{\circ} \mathrm{C}$. Preweaning mortality rate (dead pups per litter) in the C57BL and GFF strains at $-3^{\circ} \mathrm{C}$ was 3.1 and 2.8 , respectively, compared with 2.2 and 0.9 , respectively, at $21^{\circ} \mathrm{C}$. Wilson et al. (1972) reported a higher preweaning mortality in the cold $\left(12^{\circ} \mathrm{C}\right)$ than in the normal $\left(21^{\circ} \mathrm{C}\right)$ and hot $\left(30^{\circ} \mathrm{C}\right)$ environments in two composite strains of mice and attributed the higher mortality in the cold environment to mortality of whole litters rather than consistently high mortality within litters. Barnett (1965) pointed out that one of the adverse effects of cold on female reproduction might be the death of young, hairless pups, especially in the first few days after birth. Mortality rate in the hot environment, though significantly different from that in the normal environment, was far less than in the cold environment. This could be an indication that the composite base of these lines of mice can withstand heat stress more efficiently than cold stress, at least within the range of relative cold and heat stresses achieved by these thermal environments. In addition, the level of heat stress was probably less severe than the level of cold stress.

Postweaning survival rates were different $(P<0.05)$ between mice raised in the hot and cold environments. Mice in the hot environment had a higher survival rate than those in the cold environment and there was no indication of asymmetry of temperature effects. The survival rate was also similar between the males and females and averaged 96.7 and $97.7 \%$, respectively. All the above findings serve to further indicate that the composite base of these lines of mice can withstand heat stress more efficiently than cold stress.

There was a difference $(P<0.005)$ in weaning weight ( 3 wk of age) between pups raised in the hot and cold $(13.80$ vs. $11.54 \mathrm{~g})$ environments, and there was also asymmetry of $(P<0.02)$ of temperature effect on preweaning growth, where weights in the normal environment exceeded those in the extremes. At weaning, pups in the normal environment were 22 and $2.3 \%$ heavier than those in the cold and hot environmental conditions, respectively. Preweaning growth was therefore more depressed in the cold than in the hot environment. The above findings are consistent with those reported by Biggers et al. (1958), who observed that growth of mice in the cold environment $\left(5^{\circ} \mathrm{C}\right)$ was more depressed than in the hot environment and also noted very small and nonsignificant differences between mice in the hot $\left(28^{\circ} \mathrm{C}\right)$ and temperate $\left(21^{\circ} \mathrm{C}\right)$ environments. Wilson et al. (1972) reported 3-wk body weights of 9.49, 12.07, and $12.14 \mathrm{~g}$ in a four-way composite strain of mice in the cold $\left(12^{\circ} \mathrm{C}\right)$, normal $\left(21^{\circ} \mathrm{C}\right)$, and hot $\left(30^{\circ} \mathrm{C}\right)$ environments, respectively, also confirming more depressed growth in the cold than in the hot environment.

Environmental differences in corticosterone concentration were not detected in sires or pups. In pups, corticosterone level in females was greater $(P<0.04)$ than males ( $232 \pm 26$ vs. $111 \pm 27)$. Environment was a significant source of variation for serum concentration of T3 in all age groups, and it was mostly explained by the contrast of $(\mathrm{H}-\mathrm{C})$, with serum levels produced under the $\mathrm{C}$ environment being greater than under the $\mathrm{H}$. This is consistent with the greater metabolic rate to stimulate heat production under cold stress (Reichlin et al., 1973; Kopecky et al., 1986).

\section{Summary}

Failure to detect line $\times$ environment interactions for conception rate, preweaning mortality, postweaning survival rate, body temperature, and T3 and T4 levels is not consistent with the a priori hypothesis, which postulated the existence of line $\times$ environment interactions for the above traits. This indicates that the lines were similarly affected by different environmental tem- 
peratures, and no line was at an advantage or a disadvantage for any of the above traits under different environmental temperatures. This suggests that the lines were able to make some metabolic, morphological (changes in pelage density), and behavioral (changes in activity levels, huddling, etc.) adjustments to accommodate different environmental temperatures.

Litter size and corticosterone level were affected by significant line $\times$ environment interactions. However, the line selected for low heat loss, and hence low maintenance energy intake, did not have poorer litter size and did not exhibit greater stress as measured by corticosterone level than the other lines when exposed to variations of thermal environment.

\section{Implications}

No line $\times$ environment interactions were detected for conception rate, preweaning mortality, or postweaning survival rate. This implies that all lines compared similarly when reared in hot and cold environmental temperatures as when reared in normal temperature for all these traits, possibly through some physiological, morphological, and behavioral adjustments. Significant line $\times$ environment interactions were detected for litter size born and corticosterone concentration in dams. But, the line selected for low heat loss, and hence low maintenance energy intake, did not perform poorer relative to the other lines when exposed to differing thermal environments. Thus, results from this study with mice do not raise concern that selection to decrease maintenance requirements in livestock will produce animals with any greater liability to cope and perform under an array of environmental temperatures.

\section{Literature Cited}

Azzam, S. M., J. E. Kinder, and M. K. Nielsen. 1989. Conception rate at first conception in beef cattle: Effects of season, age and previous reproductive performance. J. Anim. Sci. 67:1405-1410.

Bishop, S. C., and W. G. Hill. 1985. Effects of selection for growth, body composition, and food intake in mice. III. Correlated responses: Growth, body composition, food intake, and efficiency and catabolism. Genet. Res. 46:57-74.

Barnett, S. A. 1965. Adaptation of mice to cold. Biol. Rev. 40:5-47.
Barnett, S. A., and B. M. Manly. 1956. Reproduction and growth of mice of three strains after transfer to $-3^{\circ} \mathrm{C}$. J. Exp. Biol. 33:325-329.

Biggers, J. D., M. R. Ashoub, and A. McLaren. 1958. The growth and development of mice in three climatic environments. J. Exp. Biol. 35:144-155.

Gart, J. J., and J. R. Zweifel. 1967. On the bias of various estimators of the logit and its variance with application to quantal bioassay. Biometrika 54:181-187.

Gianola, D. 1982. Theory and analysis of threshold characters. J. Anim. Sci. 54:1079-1096.

Gordon, C. J. 1993. Temperature regulation in laboratory rodents. Press Syndicate, Cambridge Univ. Press, New York.

Kopecky, J., L. Sigurdson, I. R. A. Park, and J. Himms-Hagen. 1986. Thyroxine $5^{\prime}$-deiodinase in hamster and rat brown fat adipose tissue: Effect of cold and diet. Am. J. Physiol. 251:E1-E7.

Kgwatalala, P. M., and M. K. Nielsen. 2004. Performance of mouse lines divergently selected for heat loss when exposed to different environmental temperatures. II. Feed intake, growth, fatness and body organs. J. Anim. Sci. 82:2884-2891.

Littell, R. C., G. A. Milliken, W. W. Stroup, and R. A. Wolfinger. 1996. SAS System for mixed models. SAS Inst., Inc., Cary, NC.

Maskrey, M., P. R. Wiggins, and P. B. Frappell. 2001. Behavioral thermoregulation in obese and lean Zucker rats in a thermal gradient. Am. J. Physiol. Regul. Integr. Comp. Physiol. 281:R1675-R1680.

Mousel, M. R., W. W. Stroup, and M. K. Nielsen. 2001. Locomotor activity, core body temperature and circadian rhythms in mice selected for high or low heat loss. J. Anim. Sci. 79:861-868.

Nielsen, M. K., B. A. Freking, L. D. Jones, S. M. Nelson, T. L. Vordenstrass, and B. A. Hussey. 1997a. Divergent selection for heat loss in mice: II. Correlated responses in feed intake, body mass, body composition and number born through fifteen generations. J. Anim. Sci. 75:1469-1476.

Nielsen, M. K., L. D. Jones, B. A. Freking, and J. A. DeShazer. 1997b. Divergent selection for heat loss in mice: I. Selection applied and direct response through fifteen generations. J. Anim. Sci. 75:1461-1468.

Reichlin, S., J. Bollinger, I. Nejad, and P. Sullivan. 1973. Tissue thyroid concentration of rat and man determined by radioimmunoassay: Biological significance. Mt. Sinai J. Med. 40:502-510.

Rutledge, J. J., and F. C. Gunsett. 1982. Analysis of categorical data in animal sciences. J. Anim. Sci. 54:1072-1078.

Selman, C., T. K. Korhonen, L. Bunger, W. G. Hill, and J. R. Speakman. 2001. Thermoregulatory response of two mouse Mus musculus strains selectively bred for high and low feed intake. J. Comp. Physiol. 8:661-668.

Wettemann, R. L., M. E. Wells, I. T. Omtvedt, C. E. Pope, and E. J. Turman. 1976. Influence of elevated ambient temperature on reproductive performance of boars. J. Anim. Sci. 42:664-669.

Wilson, S. P., D. P. Doolittle, T. G. Dunn, and P. V. Malven. 1972. Effect of temperature stress on growth, reproduction, and adrenocortical function of mice. J. Hered. 63:324-330. 